\title{
Evidence that the Superoxide-Generating System of Human Leukocytes Is Associated with the Cell Surface
}

\author{
Ira M. Goldstein, Manuel Cerqueira, Stuart Lind, and Howard B. Kaplan \\ From the Department of Medicine, Division of Rheumatology, New York University Medical Center, \\ New York 10016
}

A B S T R A C T Superoxide anion $\left(\mathrm{O}_{2}^{-} \cdot\right)$ generation by human peripheral blood polymorphonuclear leukocytes is enhanced when these cells encounter appropriate soluble or particulate stimuli. $\mathrm{O}_{2}^{-} \cdot$ generation requires intact, viable cells and proceeds independently of phagocytosis. To investigate the possibility that the $\mathrm{O}_{2}^{-} \cdot$-generating system is associated with the outer surface of the polymorphonuclear leukocyte plasma membrane, we have examined the effects upon $\mathrm{O}_{2}^{-}$. production of $\rho$-diazobenzenesulfonic acid, a reagent which can react predominantly with proteins of the external cell membrane. When normal human polymorphonuclear leukocytes were preincubated with cytochalasin B (to minimize endocytosis) and then exposed to the surface-active lectin, concanavalin A, the cells were stimulated to generate $\mathrm{O}_{2}^{-} \cdot$ in a concentration- and time-dependent fashion and selectively to discharge the granule-associated enzyme, lysozyme, into the surrounding medium. These responses, as well as cellular binding of $\left[{ }^{3} \mathrm{H}\right]$ concanavalin $\mathrm{A}$, could be blocked by $\alpha$-methyl-D-mannoside. Brief treatment $\left(<5 \mathrm{~min}\right.$ at $\left.4^{\circ} \mathrm{C}\right)$ of the cells with $\rho$-diazobenzenesulfonic acid (1.0-5.0 $\mathrm{mM}$ ) significantly interfered with concanavalin A-mediated $\mathrm{O}_{2}^{-} \cdot$ generation but had no influence upon lysozyme release or upon binding of $\left[{ }^{3} \mathrm{H}\right]$ concanavalin A. The diazonium salt did not alter cell viability or the specific activity of the cytoplasmic enzyme, lactate dehydrogenase (inhibitable under conditions which allowed entry of this reagent into the cytosol). $\rho$-Diazobenzenesulfonic acid, therefore, very likely exerted its effects at the cell surface of the intact polymorphonuclear leukocyte, selectively inhibiting $\mathrm{O}_{2}^{-} \cdot$ production (either directly or indirectly) without influencing another response to lectin-cell

Dr. Lind's present address is the Department of Medicine, Northwestern University Medical Center, Chicago, Ill. 60611. Dr. Goldstein is the recipient of a Career Scientist Award from the Irma T. Hirschl Trust.

Received for publication 18 May 1976 and in revised form 19 October 1976. contact: release of lysozyme. These results support the possibility that a polymorphonuclear leukocyte ectoenzyme is responsible for $\mathrm{O}_{2}^{-} \cdot$ production.

\section{INTRODUCTION}

There is now considerable evidence that the burst of oxidative metabolism which accompanies phagocytosis by polymorphonuclear leukocytes $(\mathrm{PMN})^{1}$ is probably initiated at the cell surface. A variety of particulate as well as surface-reactive soluble stimuli are capable of provoking increased consumption of oxygen, generation of $\mathrm{H}_{2} \mathrm{O}_{2}$, and increased utilization of glucose via the hexose monophosphate shunt pathway in the absence of phagocytosis (1-8). More direct evidence that the PMN cell surface participates in these reactions was provided recently by the demonstration by Briggs et al. (9) of an apparent ecto-enzyme which generates $\mathrm{H}_{2} \mathrm{O}_{2}$ via oxidation of NADH. A likely intermediate in this reaction is the superoxide anion $\left(\mathrm{O}_{2}^{-} \cdot\right)$ which can undergo spontaneous dismutation to yield $\mathrm{H}_{2} \mathrm{O}_{2}$, or which can be converted to this product by the action of superoxide dismutase (10). $\mathrm{O}_{2}^{-} \cdot$ generation by human PMN is also enhanced when these cells encounter appropriate soluble or particulate stimuli $(8,11-15)$. $\mathrm{O}_{2}^{-} \cdot$ generation requires intact, viable cells and proceeds independently of phagocytosis. In fact, $\mathrm{O}_{2}^{-}$. recovery in the medium surrounding $P M N$ is enhanced when formation of phagocytic vacuoles is inhibited, as after treatment of cells with cytochalasin B (13). These observations, as well as the demonstration that $\mathrm{O}_{2}^{-}$. does not appear to be released from cells as a consequence of degranulation or cell disruption, support the possibility that $\mathrm{O}_{2}^{-}$. production takes place on the outer surface of the PMN cell membrane as well as in phagocytic vacuoles which are formed by invaginations of

${ }^{1}$ Abbreviations used in this paper: Con A, concanavalin A; DBSA, $\boldsymbol{p}$-diazobenzenesulfonic acid; LDH, lactate dehydrogenase; PBS, phosphate-buffered saline; PMN, polymorphonuclear leukocyte (s). 
this membrane $(13,16)$. We have investigated this possibility by examining the effects of $\rho$-diazobenzenesulfonic acid (DBSA) upon generation of $\mathrm{O}_{2}^{-}$. by PMN. This reagent reacts predominantly with proteins of the external cell membrane $(17,18)$. As a stimulus for $\mathrm{O}_{2}^{-}$. generation, we have selected concanavalin $\mathrm{A}(\mathrm{Con} \mathrm{A})$, a lectin known to enhance the oxidative metabolism of PMN (19). We have found that DBSA treatment significantly inhibited Con A-mediated $\mathrm{O}_{2}^{-} \cdot$ generation without influencing another PMN response to surface stimulation by this ligand: secretion of the granuleassociated enzyme, lysozyme (20).

\section{METHODS}

Preparation of leukocyte suspensions. $32 \mathrm{ml}$ of venous blood from healthy adult donors was allowed to sediment at room temperature after mixing with $8 \mathrm{ml}$ acid citrate dextrose (National Institutes of Health formula A) and $20 \mathrm{ml} 6 \%$ dextran (average mol wt, 234,000, Sigma Chemical Co., St. Louis, Mo.) in $140 \mathrm{mM} \mathrm{NaCl}$. $35 \mathrm{ml}$ of $0.87 \% \mathrm{NH}_{4} \mathrm{Cl}$ was added to $15-\mathrm{ml}$ aliquots of the leukocyte-rich supernates and the mixtures were centrifuged at $155 \mathrm{~g}$ for $10 \mathrm{~min}$. Pellets were washed once with $140 \mathrm{mM} \mathrm{NaCl}$ and finally suspended in phosphatebuffered saline (Dulbecco's PBS, Grand Island Biological Co., Grand Island, N. Y.) supplemented with $0.6 \mathrm{mM} \mathrm{CaCl}$ and $1.0 \mathrm{mM} \mathrm{MgCl}_{2}$, and adjusted to $\mathrm{pH}$ 7.4. This buffer was used throughout. In some experiments purified preparations of PMN were obtained by means of Hypaque/Ficoll gradients (Pharmacia Fine Chemicals Inc., Piscataway, N. J.) (21), allowing studies of cell suspensions containing $98 \pm 1 \%$ PMN without contaminating platelets or erythrocytes.

Preparation of DBSA. DBSA was prepared by the indirect method (17) as described previously by DePierre and Karnovsky (18). Actual yields of DBSA obtained by this method were determined by titration with histidine hydrochloride (Sigma Chemical Co.) (22). Yields of DBSA determined by this method were found generally to be within $75-80 \%$ of predicted values and correlated quite well with yields determined by employing radiolabeled sulfanilic acid ${ }^{35}$ S-sulfanilic acid, Amersham/Searle Corp., Arlington Heights, Ill.) (18).

Treatment of leukocytes with DBSA. Aliquots of the leukocyte suspensions containing approximately $4 \times 10^{6}$ PMN were dispensed into $10 \times 75$-mm polypropylene tubes (Falcon Plastics, Division of BioQuest, Oxnard, Calif.) and brought to desired temperature before the addition of DBSA. The $\mathrm{pH}$ of the DBSA solution was adjusted so that the final $\mathrm{pH}$ of the reaction mixtures was approximately 7.4. After appropriate periods of incubation of cells with DBSA, 2 vol of $10 \%$ fetal calf serum (Grand Island Biological Co.) in PBS buffer was added and the reaction mixtures were centrifuged at $4^{\circ} \mathrm{C}$ for $10 \mathrm{~min}$ at $155 \mathrm{~g}$. The cell pellets were washed once with $10 \%$ fetal calf serum in PBS and once with buffer alone before being suspended in appropriate volumes of buffer. Control cell suspensions, not exposed to DBSA, were treated similarly.

Determination of leukocyte $\mathrm{O}_{2}^{-} \cdot$ generation. Duplicate reaction mixtures containing leukocytes, with or without pretreatment with DBSA, were incubated with $5.0 \mu \mathrm{g} / \mathrm{ml}$ cytochalasin B (ICI Research Laboratories, Alderley Park, Cheshire, England) in $0.1 \%$ dimethyl sulfoxide (Matheson, Coleman \& Bell, East Rutherford, N. J.) at $37^{\circ} \mathrm{C}$ for $10 \mathrm{~min}$ before addition of $75 \mu \mathrm{M}$ horse heart ferri-cytochrome $c$ (type III, Sigma Chemical Co.) and (ox) Con A (Pharmacia Fine
Chemicals, Inc.). This concentration of dimethyl sulfoxide did not influence cytochrome $c$ reduction, enzyme release, or enzyme assays (see below). $\alpha$-methyl-D-Mannoside (Sigma Chemical Co.) was also added to some reaction mixtures. Incubations were terminated by placing the tubes in ice, then they were centrifuged at $4^{\circ} \mathrm{C}$ for $10 \mathrm{~min}$ at $755 \mathrm{~g}$. Cell-free supernates were assayed for cytochrome $c$ reduction as previously described (13). Specificity of cytochrome $c$ reduction was monitored by assays of supernates from reaction mixtures to which had been added $10 \mu \mathrm{g} / \mathrm{ml}$ superoxide dismutase (Truett Laboratories, Dallas, Tex.). $\mathrm{O}_{2}^{-} \cdot$ generation has been expressed as nanomoles cytochrome $c$ reduced per $10^{6} \mathrm{PMN}$.

Measurement of leukocyte enzyme release. The extracellular release of the PMN granule-associated enzyme, lysozyme (EC 3.2.1.17) was measured as previously described (13) in duplicate reaction mixtures identical to those employed for the determination of $\mathrm{O}_{2}^{-} \cdot$ generation, but in the absence of cytochrome $c$. Release of the cytoplasmic enzyme, lactate dehydrogenase (LDH, EC 1.1.1.27) was also measured (23) and used as an indicator of cell viability (24). Cell viability was also assessed by trypan blue exclusion. Enzyme release has been expressed as the percent of total activity released by the detergent, $0.2 \%$ Triton X-100 (Rohm and Haas Co., Philadelphia, $\mathrm{Pa}$.) or by sonication in simultaneously run duplicate reaction mixtures. Protein in cell-free supernates and in lysed cell pellets was measured (25) and employed to calculate enzyme-specific activities.

Binding of Con A to leukocytes. To suspensions of either normal or DBSA-treated PMN which had been preincubated with cytochalasin B were added $1.0 \mu \mathrm{Ci}\left[{ }^{3} \mathrm{H}\right] \mathrm{Con} \mathrm{A}$ (New England Nuclear, Boston, Mass.) plus $30 \mu \mathrm{g}$ of unlabeled lectin. After $15 \mathrm{~min}$ of incubation at $37^{\circ} \mathrm{C}$, the leukocytes were sedimented ( $155 \mathrm{~g}$ for $10 \mathrm{~min}$ ), washed three times with buffer, and allowed to dry at room temperature. The dried pellets were digested with $0.5 \mathrm{ml}$ of $0.2 \mathrm{~N} \mathrm{NaOH}$ for $2 \mathrm{~h}$ at $56^{\circ} \mathrm{C}$, followed by the addition of $0.2 \mathrm{ml}$ of $3.0 \%$ acetic acid and $0.5 \mathrm{ml}$ of distilled water. $1.0-\mathrm{ml}$ aliquots were added to $20 \mathrm{ml}$ Bray's solution (26) and counted in a Beckman LS-100 liquid scintillation counter (Beckman Instruments, Inc., Spinco Div., Palo Alto, Calif.). Results have been expressed as counts per minute per $10^{6} \mathrm{PMN}$.

Binding and uptake of DBSA. For these experiments, DBSA was prepared with $14.7 \mathrm{mCi} / \mathrm{mmol}^{35} \mathrm{~S}$-sulfanilic acid (Amersham/Searle, lot 0976). Suspensions of purified PMN (from Hypaque/Ficoll gradients) were treated with radiolabeled DBSA ( $\cong 1,500 \mathrm{cpm} / \mathrm{nmol})$ and washed as described above. Total cellular binding of DBSA was measured in $\mathrm{NaOH}$ digests of washed cell pellets (as above). In addition, some suspensions were subjected to four cycles of freezing (in dry ice/acetone) and thawing before division into 100,000-g supernates and pellets $(27)$. This treatment was sufficient to release total assayable LDH. Supernates and digested pellets were counted before and after addition of trichloroacetic acid (TCA, 20\% wt/vol). Results have been expressed as TCAprecipitable counts per minute per $5 \times 10^{6} \mathrm{PMN}$.

\section{RESULTS}

DBSA treatment of PMN. To determine the optimal conditions for treating PMN with DBSA, various combinations of time, temperature, and concentration were tested. Incubation at $37^{\circ} \mathrm{C}$ for greater than $10 \mathrm{~min}$ with $1.0 \mathrm{mM}$ DBSA led to slight but reproducible reductions in the total cellular activity and specific activity of PMN cytoplasmic LDH (Table I), indicating that 
TABLE I

Uptake of DBSA by PMN and Effects upon Enzyme Activities

\begin{tabular}{|c|c|c|c|c|}
\hline \multirow{2}{*}{$\begin{array}{l}\text { Treatment of } \\
\text { PMN* }^{*}\end{array}$} & \multicolumn{2}{|c|}{$\begin{array}{l}\text { Enzyme-specific } \\
\text { activities }\end{array}$} & \multicolumn{2}{|c|}{$\begin{array}{c}\text { Uptake of }{ }^{35} S \text {-DBSA, } \\
\text { cpm } \S\end{array}$} \\
\hline & LDH & Lysozyme & Pellet & Supernate \\
\hline None & $1.21 \pm 0.21$ & $6.52 \pm 0.31$ & - & - \\
\hline $\begin{array}{r}\text { DBSA }(1.0 \mathrm{mM} \text {, } \\
\left.15 \mathrm{~min}, 37^{\circ} \mathrm{C}\right)\end{array}$ & $0.99 \pm 0.18$ & $6.10 \pm 0.40$ & $11,014 \pm 346$ & $1,190 \pm 96$ \\
\hline $\begin{array}{l}\text { DBSA }(5.0 \mathrm{mM}, \\
\left.2 \mathrm{~min}, 4^{\circ} \mathrm{C}\right)\end{array}$ & $1.23 \pm 0.23$ & $6.50 \pm 0.29$ & $1,053 \pm 36$ & $-4 \pm 7$ \\
\hline
\end{tabular}

* PMN were treated as described with either routinely prepared DBSA or DBSA prepared with ${ }^{35} \mathrm{~S}$-sulfanilic acid. Cells were disrupted by sonication or by freezing and thawing. Protein and enzyme activities were assayed in supemates after centrifugation at $2,000 \mathrm{~g}$ for $10 \mathrm{~min}$.

t LDH, absorbance units/microgram protein. Lysozyme, micrograms crystalline hen egg-white lysozyme equivalents/100 $\mu$ g protein. Mean \pm SEM, $n=3$.

$\$$ TCA-precipitable counts in $100,000 \mathrm{~g}$ pellets and supernates of treated cells after freezing and thawing $(20 \% \mathrm{TCA}, \mathrm{wt} / \mathrm{vol})$

under these conditions, DBSA had penetrated into the cells. As in previous studies (18), if PMN were disrupted either by freezing and thawing or with Triton $\mathrm{X}-100$, the activity of LDH could be promptly inhibited by DBSA (completely with $1.0 \mathrm{mM}$ DBSA and significantly with $0.01 \mathrm{mM}$ DBSA). Entry of DBSA into cells was confirmed by experiments employing a radiolabeled reagent. When PMN were incubated for $15 \mathrm{~min}$ at $37^{\circ} \mathrm{C}$ with $1.0 \mathrm{mM}{ }^{35} \mathrm{~S}$-DBSA, approximately $10 \%$ of cell-associated, TCA-precipitable counts were detected in 100,000-g supernates of cells after freezing and thawing. Similar time- and temperature-dependent entry of this reagent into cells have been reported for guinea pig peritoneal PMN (18) and for human erythrocytes (17). Consequently, to reduce the possibility for permeation across the plasma membrane, we elected to expose cells to DBSA for very brief durations and at reduced temperatures. DBSA has been demonstrated to be a nonpenetrating reagent under these conditions $(17,18,28)$. At $4^{\circ} \mathrm{C}$, for example, and for durations of less than $5 \mathrm{~min}, \mathrm{PMN}$ could be exposed to $5.0 \mathrm{mM}$ DBSA without any alterations in cellular integrity (measured by trypan blue exclusion and by leakage of cytoplasmic LDH) or changes in the specific activity and content of cellular enzymes (lysozyme and LDH). Furthermore, no TCA-precipitable counts were detected in 100,000-g supernates after freezing and thawing PMN which had been exposed to $5.0 \mathrm{mM}$ ${ }^{35} \mathrm{~S}$-DBSA for $2 \mathrm{~min}$ at $4^{\circ} \mathrm{C}$. Consequently, these conditions were employed in the experiments described below.

Effect of DBSA treatment upon Con-A-mediated $\mathrm{PMN} \mathrm{O}_{2}^{-} \cdot$ generation and lysozyme release. Con $\mathrm{A}$ stimulated PMN to generate enhanced amounts of $\mathrm{O}_{2}^{-}$. (measured as superoxide dismutase-inhibitable cytochrome $c$ reduction) and to release selectively the granule-associated enzyme, lysozyme, in a time- and concentration-related fashion (Figs. 1 and 2). These

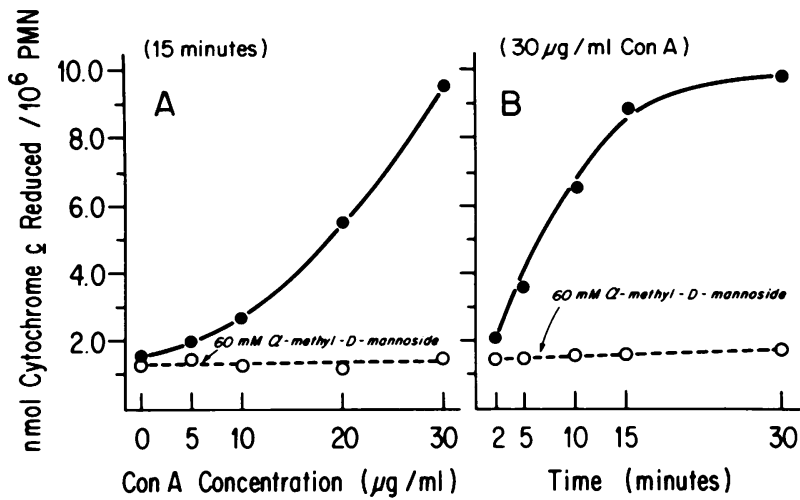

FIGURE 1 Superoxide generation by cytochalasin B-treated PMN exposed to Con $A$ in the presence $(O)$ or absence $(O)$ of $60 \mathrm{mM} \alpha$-methyl-D-mannoside: (A) versus concentration of Con A (15 min incubation), (B) versus duration of incubation $(30 \mu \mathrm{g} / \mathrm{ml}$ Con A). Results are expressed as nmoles cytochrome $c$ reduced per $10^{6} \mathrm{PMN}$.

responses to Con A were abolished if $60 \mathrm{mM} \alpha$-methylD-mannoside was also present in the reaction mixtures. In the absence of cells, Con A or $\alpha$-methyl-D-mannoside neither influenced cytochrome $c$ reduction nor lysozyme activity. When DBSA-treated cells were exposed to $\mathrm{Con} \mathrm{A}, \mathrm{O}_{2}^{-}$. generation was reduced, whereas lysozyme release was unaffected (Table II). Inhibition of $\mathrm{O}_{2}^{-}$. generation varied (but not significantly) with the concentration of DBSA which was employed to pretreat the PMN, but was not associated with cytotoxicity (measured as "leakage" of cytoplasmic LDH). Results identical to those described above were obtained in experiments employing cell suspensions which contained 98 $\pm 1 \%$ PMN (from Hypaque/Ficoll gradients). When DBSA was em-

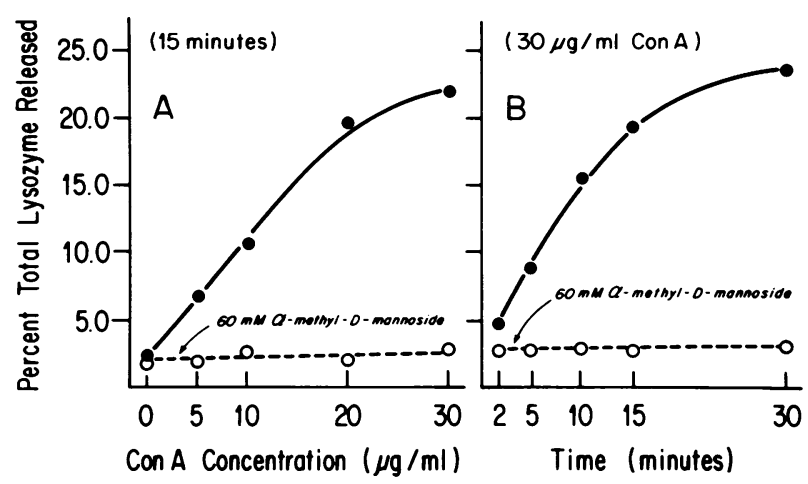

FIGURE 2 Lysozyme release from cytochalasin B-treated PMN exposed to Con $A$ in the presence $(O)$ or absence $(O)$ of $60 \mathrm{mM} \alpha$-methyl-D-mannoside: (A) versus concentration of Con A (15 min incubation), (B) versus duration of incubation (30 $\mu \mathrm{g} / \mathrm{ml}$ Con A). Lysozyme activity in cell-free supernates is expressed as the percent of total activity released by $0.2 \%$ Triton X-100 in simultaneously run duplicate reaction mixtures (Table II). 
TABLE II

Influence of DBSA Treatment upon Con A-Mediated PMN Enzyme Release and Superoxide Generation

\begin{tabular}{|c|c|c|c|}
\hline \multirow[b]{2}{*}{ Treatment of PMN* } & \multirow{2}{*}{$\begin{array}{l}\text { Superoxide generation, } \\
\text { nmol cytochrome c reduced / } \\
10^{6} \mathrm{PMN} / 15 \mathrm{~min}\end{array}$} & \multicolumn{2}{|c|}{$\begin{array}{c}\text { Total enzyme } \\
\text { activity released, } \downarrow \\
\%\end{array}$} \\
\hline & & Lysozyme & LDH \\
\hline None (control) & $1.2 \pm 0.1$ & $1.3 \pm 0.6$ & $1.0 \pm 0.1$ \\
\hline Con A $(30 \mu \mathrm{g} / \mathrm{ml})$ & $8.3 \pm 0.7$ & $22.8 \pm 1.8$ & $1.1 \pm 0.2$ \\
\hline DBSA $(5.0 \mathrm{mM})+$ Con A & $4.4 \pm 0.6 \S$ & $24.2 \pm 1.7$ & $0.9 \pm 0.1$ \\
\hline$(2.5 \mathrm{mM})+$ Con $\mathrm{A}$ & $5.0 \pm 0.7$ & $22.4 \pm 2.3$ & $1.0 \pm 0.1$ \\
\hline$(1.0 \mathrm{mM})+\operatorname{Con} \mathrm{A}$ & $5.9 \pm 0.7$ & $23.9 \pm 3.3$ & $0.9 \pm 0.2$ \\
\hline
\end{tabular}

* PMN were treated as indicated with DBSA for 2 min at $4^{\circ} \mathrm{C}$, preincubated with $5.0 \mu \mathrm{g} / \mathrm{ml}$ cytochalasin $B$ for $10 \mathrm{~min}$ at $37^{\circ} \mathrm{C}$, and exposed to Con A for $15 \mathrm{~min}$ at $37^{\circ} \mathrm{C}$.

† Expressed as percent of total (100\%) activity released by Triton X-100: $100 \%$ lysozyme $=7.4 \mu \mathrm{g} \pm 1.4$ crystalline hen egg-white lysozyme equivalents $/ 2 \times 10^{\circ}$ leukocytes. $100 \%$ LDH (lactate dehydrogenase) $=874 \pm 89 \mathrm{AU} / 2 \times 10^{6}$ leukocytes. Mean \pm SEM, $n$ (number of experiments) $=10$.

$\$ P$ vs. Con A alone $<0.001$ (Student's $t$ test).

" $P$ vs. Con A alone $<0.005$; vs. DBSA $(5.0 \mathrm{mM})+$ Con A $>0.25$ (Student's $t$ test).

I $P$ vs. Con A alone $<0.01$; vs. DBSA $(5.0 \mathrm{mM})+$ Con A $>0.05$ (Student's $t$ test).

ployed at concentrations greater than $5.0 \mathrm{mM}$, superoxide generation was reduced even further (results not shown). This, however, was associated with indications of cytotoxicity (enhanced release of LDH and decreased trypan blue exclusion). Consequently, this effect of DBSA was not pursued further. Whereas DBSA per se was capable of oxidizing cytochrome $c$, appropriate experiments excluded this phenomenon as accounting for the observed results. Concentrations of DBSA below $0.05 \mathrm{mM}$ had no effect upon cytochrome $c$ (either reduction or oxidation) nor did DBSAtreated PMN when these were mixed with normal cells exposed to Con A. Predicted amounts of cytochrome $c$ reduction were observed in the latter experiments (a representative experiment is shown in Table III). These results indicated not only that our method of washing DBSA-treated cells was sufficient to remove any unbound diazonium salt which could potentially interfere with cytochrome $c$ reduction, but also that bound DBSA had no apparent effect on the assay system (i.e., did not influence cytochrome $c$ reduction by normal cells). Furthermore, additional control experiments excluded the possibilities that DBSA treatment influenced the enzyme assays or that there was selective adsorption of enzymes to cells after their release into the suspending buffer.

Binding of radiolabeled Con A to PMN did not appear to be influenced by prior treatment of the cells with DBSA (Fig. 3). Furthermore, binding of Con A to normal or to DBSA-treated cells was appropriately inhibited by $\alpha$-methyl-D-mannisode. Virtually complete inhibition of binding was observed in the presence of concentrations of this sugar exceeding $60 \mathrm{mM}$.

\section{DISCUSSION}

Con A has previously been shown capable of stimulating oxygen consumption and hexose monophosphate shunt activity in PMN (19), as well as provoking discharge from these cells, by exocytosis, of the granuleassociated enzyme, lysozyme (20). Our results indicate that the lectin is also a potent stimulus for $\mathrm{O}_{2}^{-}$. production by PMN, even under conditions (cytochalasin B treatment) which retard its internalization (20). Stimulation of $\mathrm{O}_{2}^{-}$. production was appropriately inhibited by $\alpha$-methyl-D-mannoside, a sugar which effectively competes with cell "receptors" for Con A (29). Our results provide, moreover, another example of enhanced $\mathrm{O}_{2}^{-}$. generation after PMN cell-surface stimulation as well as further evidence that the PMN $\mathrm{O}_{2}^{-} \cdot$-generating system is associated with the cell surface.

The hypothesis that the $\mathrm{PMN} \mathrm{O}_{2}^{-} \cdot$-generating system is localized to the external surface of the plasma membrane is attractive. Surface generation of $\mathrm{O}_{2}^{-}$. (and of its product, $\mathrm{H}_{2} \mathrm{O}_{2}$ ) would allow for its concentration within phagocytic vacuoles and provides a convenient explanation for the extracellular recovery of this highly reactive free radical. There is, in fact, no readily apparent alternative hypothesis which would account for the ability of $\mathrm{O}_{2}^{-}$. to diffuse from cells (which contain superoxide dismutase in their cytoplasm) without producing lethal membrane damage. Indeed, Salin and McCord (30) have provided evidence of $\mathrm{O}_{2}^{-} \cdot$-mediated lethal injury to PMN. Direct evidence for such a PMN ectoenzyme is lacking, but there is strong supportive evidence. For example, the recently described surface NADH oxidase of the human PMN, which produces $\mathrm{H}_{2} \mathrm{O}_{2}$, could very well be an $\mathrm{O}_{2}^{-} \cdot$-generating system (9). It is likely that $\mathrm{O}_{2}^{-} \cdot$ is an important intermediate in $\mathrm{H}_{2} \mathrm{O}_{2}$ generation $(8,9,13,31)$.

Inhibition of intact cell enzyme activity by "nonpenetrating" reagents represents one experimental

\section{TABLE III}

DBSA-Treated Leukocytes: Influence on the Reduction of Cytochrome c by Normal Leukocytes which Have Been Stimulated with Con A

\begin{tabular}{|c|c|}
\hline Reaction mixtures* & $\begin{array}{l}\text { nmol Cytochrome } c \\
\text { reduced/10 } \mathrm{PMN} / 15 \mathrm{~min}\end{array}$ \\
\hline$A=$ Normal PMN $\left(4 \times 10^{6}\right)$ & \\
\hline $\begin{array}{l}+ \text { Con A }(30 \mu \mathrm{g} / \mathrm{ml}) \\
\text { B }=\text { DBSA }(50 \mathrm{mM}) \text {-treated PMN }\left(4 \times 10^{6}\right)\end{array}$ & 9.6 \\
\hline+ Con A $(30 \mu \mathrm{g} / \mathrm{ml})$ & 4.0 \\
\hline$A+B\left(8 \times 10^{6} \mathrm{PMN}\right)$ & $6.9 \ddagger$ \\
\hline
\end{tabular}

* PMN were exposed to DBSA for 2 min at $4^{\circ} \mathrm{C}$ and washed. Cells were preincubated with cytochalasin B $(5.0 \mu \mathrm{g} / \mathrm{ml})$ for $10 \mathrm{~min}$ before exposure to Con $\mathrm{A}$ for $15 \mathrm{~min}$ at $37^{\circ} \mathrm{C}$. $\ddagger$ Expected value $=6.8 \mathrm{nmol} / 10^{6} \mathrm{PMN}$. 
method that can be employed to test whether a cellular enzyme has active sites directly exposed to the external milieu (18). DBSA, under appropriate conditions, is such a nonpenetrating reagent. It is capable of forming covalent bonds with sulfhydryl, amino, and phenolic groups in proteins and its polar nature would hinder translocation across the hydrophobic bilayers of intact cells $(32,33)$. DBSA has previously been employed to label surface proteins of the human erythrocyte (17) and to demonstrate that adenosine monophosphate was an ectoenzyme of guinea pig PMN (18).

We have found that brief $(<5 \mathrm{~min})$ treatment at $4^{\circ} \mathrm{C}$ of human PMN with DBSA significantly interfered with $\mathrm{O}_{2}^{-}$. generation when these cells were subsequently exposed to Con A. Under conditions sufficient to inhibit Con A-mediated $\mathrm{O}_{2}^{-}$. production significantly, DBSA neither altered cell viability nor the specific activity of the PMN cytoplasmic enzyme, LDH. This enzyme was inhibitable by DBSA under conditions (prolonged incubation at $37^{\circ} \mathrm{C}$ or after treatment with Triton X-100) which allowed access of this reagent to the cytosol (Table I). Although it appeared that DBSA exerted its effects at the cell surface of the intact $\mathrm{PMN}$ to selectively inhibit $\mathrm{O}_{2}^{-}$. production, other possibilities had to be considered. In contrast to adenosine monophosphate activity of the guinea pig PMN (18), $\mathrm{O}_{2}^{-} \cdot$-generating activity of human PMN depends upon exogenous cell surface stimulation (13). Consequently, DBSA may have acted primarily upon surface proteins which are "linked" to, or activate, the enzyme system rather than upon the enzyme per se. Thus, some independent measurements of stimulusmembrane interactions were required. This formed the basis for the strategy of employing Con $\mathrm{A}$ as a stimulus. First, Con A binds predominantly to sugar moieties which were unlikely to be affected by DBSA (29). Second, binding of Con A could be quantitatively measured. Third, phagocytosis of internalization of Con A are not prerequisites for its stimulatory effects. To further minimize phagocytosis or internalization as variables, cytochalasin $B$ was employed $(13,20){ }^{2}$ Finally, another response of PMN to cell surface stimulation by Con A could be measured, i.e., the extracellular release of lysozyme. Our experiments revealed that DBSA neither influenced binding of Con A to PMN nor the release of lysozyme that occurs as a consequence of such binding. These measurements of

\footnotetext{
${ }^{2}$ In studies not described here, DBSA was found to markedly interfere with phagocytosis by PMN of serumtreated zymosan particles and opsonized paraffin oil droplets, thus excluding these as possible stimuli. The effects of Con A and of DBSA upon PMN in the absence of cytochalasin B were qualitatively and quantitatively similar to those observed in the presence of this compound. However, since measurements of internalization of Con A in these experiments were not performed, these data are not presented.
}

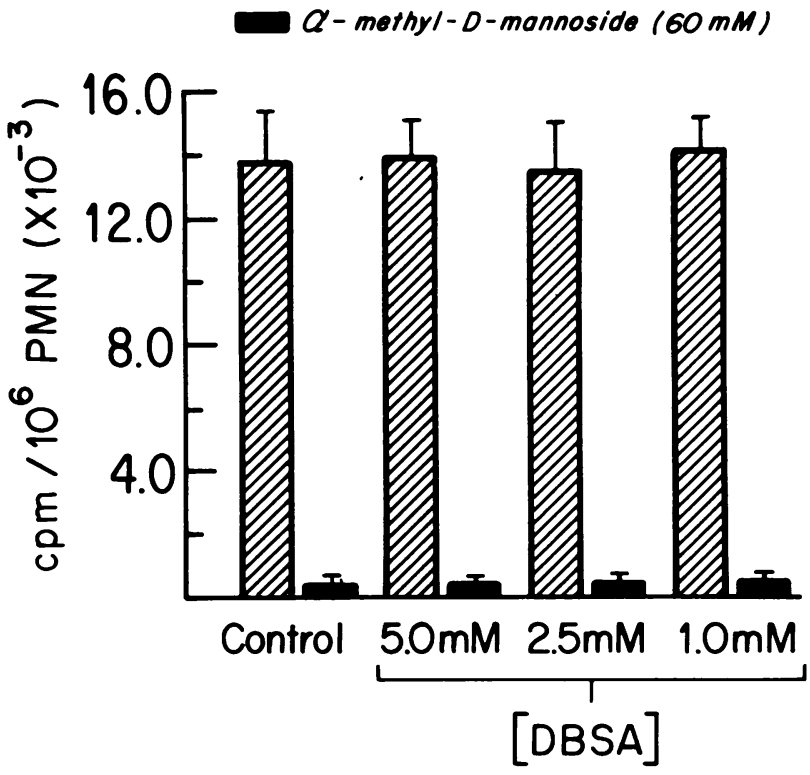

FIgURE $3 \quad\left[{ }^{3} \mathrm{H}\right]$ Con A binding to normal (control) and DBSAtreated PMN in the presence (solid bars) and absence (hatched bars) of $60 \mathrm{mM} \alpha$-methyl-D-mannoside. PMN were exposed to DBSA for $2 \mathrm{~min}$ at $4^{\circ} \mathrm{C}$. Cells were preincubated with cytochalasin $B(5.0 \mu \mathrm{g} / \mathrm{ml})$ for $10 \mathrm{~min}$ before exposure to $\left[{ }^{3} \mathrm{H}\right] \mathrm{Con} \mathrm{A}(1.0 \mu \mathrm{Ci})$ for $15 \mathrm{~min}$ at $37^{\circ} \mathrm{C}$.

stimulus-membrane interactions support the possibility that DBSA acted primarily at the cell surface of intact $\mathrm{PMN}$ to selectively inhibit $\mathrm{O}_{2}^{-}$. production without influencing other responses to cell surface stimulation. No conclusion, however, can be drawn from these experiments regarding possible effects of DBSA upon surface proteins which "activate" the $\mathrm{O}_{2}^{-} \cdot$-generating system. Furthermore, since greater than $50 \%$ inhibition of $\mathrm{O}_{2}^{-} \cdot$ generation by DBSA was associated with cytotoxicity, these experiments do not exclude the possibility that some $\mathrm{O}_{2}^{-} \cdot$ is produced at a site which was not accessible to the "nonpenetrating" reagent. Nevertheless, our results do support the hypothesis that the PMN $\mathrm{O}_{2}^{-} \cdot$-generating system is an ectoenzyme and provide additional evidence that the burst of oxidative metabolism which normally accompanies particle contact and phagocytosis by PMN is initiated at the cell surface.

\section{ACKNOWLEDGMENTS}

The authors thank Dr. Gerald Weissmann for his advice and his critical review of this manuscript.

This research was supported by grants from the National Institutes of Health (AM-18531, AM-11949, and HL-15140) and Whitehall, National, and National Science Foundations.

\section{REFERENCES}

1. Graham, R. C., Jr., M. J. Karnovsky, A. W. Shafer, E. A. Glass, and M. L. Karnovsky. 1967. Metabolic and 
morphological observations on the effect of surfaceactive agents on leukocytes. J. Cell Biol. 32: 629-647.

2. Rossi, F., M. Zatti, P. Patriarca, and R. Cramer. 1971. Effect of specific antibodies on the metabolism of guinea pig polymorphonuclear leukocytes. J. Reticuloendothel. Soc. 9: 67-85.

3. Kaplan, S. S., S. C. Finch, and R. E. Basford. 1972. Polymorphonuclear leukocyte activation: Effects of phospholipase C. Proc. Soc. Exp. Biol. Med. 140: 540-543.

4. Repine, J. E., J. G. White, C. C. Clawson, and B. M. Holmes. 1974. The influence of phorbol myristate acetate on oxygen consumption by polymorphonuclear leukocytes. J. Lab. Clin. Med. 83: 911-920.

5. Goldstein, I. M., F. Feit, and G. Weissman. 1975. Enhancement of nitroblue tetrazolium dye reduction by leukocytes exposed to a component of complement in the absence of phagocytosis. J. Immunol. 114: 516-518.

6. Tedesco, F., S. Trani, M. R. Soranzo, and P. Patriarca. 1975. Stimulation of glucose oxidation in human polymorphonuclear leukocytes by C3-Sepharose and soluble C567. FEBS (Fed. Eur. Biochem. Soc.) Lett. 51: 232-236.

7. Henson, P. M., and Z. G. Oades. 1975. Stimulation of human neutrophils by soluble and insoluble immunoglobulin aggregates. Secretion of granule constituents and increased oxidation of glucose. J. Clin. Invest. 56: 10531061.

8. Root, R. K., and J. Metcalf. 1976. Initiation of granulocyte (PMN) $\mathrm{O}_{2}^{-} \cdot$ and $\mathrm{H}_{2} \mathrm{O}_{2}$ formation by stimulation of membrane phagocytic receptors (PR). Clin. Res. 24: 352 (Abstr.)

9. Briggs, R. T., D. B. Drath, M. L. Karnovsky, and M. J. Karnovsky. 1975. Localization of NADH oxidase on the surface of human polymorphonuclear leukocytes by a new cytochemical method. J. Cell Biol. 67: 566-586.

10. McCord, J. M., and I. Fridovich. 1969. Superoxide dismutase. An enzymatic function for erythrocuprein (hemocuprein). J. Biol. Chem. 244: 6049-6055.

11. Babior, B. M., R. S. Kipnes, and J. T. Curnutte. 1973. Biological defense mechanisms. The production by leukocytes of superoxide, a potential bactericidal agent. J. Clin. Invest. 52: 741-744.

12. Curnutte, J. T., and B. M. Babior. 1974. Biological defense mechanisms. The effect of bacteria and serum on superoxide production by granulocytes.J. Clin. Invest. 53: $1662-1672$.

13. Goldstein, I. M., D. Roos, H. B. Kaplan, and G. Weissmann. 1975. Complement and immunoglobulins stimulate superoxide production by human leukocytes independently of phagocytosis. J. Clin. Invest. 56: 11551163.

14. Johnston, R. B., Jr., and J. E. Lehmeyer. 1976. Elaboration of toxic oxygen by-products by neutrophils in a model of immune complex disease. J. Clin. Invest. 57: 836-841.

15. Goldstein, I. M., H. B. Kaplan, A. Radin, and M. Frosch. 1976. Independent effects of IgG and complement upon human polymorphonuclear leukocyte function. J. Immunol. 117: 1282-1287.

16. Salin, M. L., and J. M. McCord. 1974. Superoxide dismutase in polymorphonuclear leukocytes. J. Clin. Invest. 54: 1005-1009.

17. Berg, H. C. 1969. Sulfanilic acid diazonium salt: A label for the outside of the human erythrocyte membrane. Biochim. Biophys. Acta. 183: 65-78.
18. DePierre, J. W., and M. L. Karnovsky. 1974. Ecto-enzymes of the guinea pig polymorphonuclear leukocyte. I. Evidence for an ecto-adenosine monophosphatase, -adenosine triphosphatase, and $\rho$-nitrophenyl phosphatase. J. Biol. Chem. 249: 7111-7120.

19. Romeo, D., G. Zabucchi, and F. Rossi. 1973. Reversible metabolic stimulation of polymorphonuclear leukocytes and macrophages by concanavalin A. Nat. New Biol. 243: $111-112$.

20. Hoffstein, S., R. Soberman, I. Goldstein, and G. Weissmann. 1976. Concanavalin A induces microtubule assembly and specific granule discharge in human polymorphonuclear leukocytes. J. Cell Biol. 68: 781-787.

21. Boyum, A. 1968. Isolation of mononuclear cells and granulocytes from human blood. Isolation of mononuclear cells by one centrifugation, and of granulocytes by combining centrifugation and sedimentation at $1 \mathrm{~g}$. Scand. J. Clin. Lab. Invest. 21 (Suppl. 97): 77-89.

22. Higgins, H. G., and D. Fraser. 1952. The reaction of amino acids and proteins with diazonium compounds. I. A spectrophotometric study of azo derivatives of histidine and tyrosine. Aust. J. Sci. Res., Ser. A. 5: 736-753.

23. Wacker, W. E. C., D. D. Ulmer, and B. L. Vallee. 1956. Metalloenzymes and myocardial infarction. II. Malic and lactic dehydrogenase activities and zinc concentration in serum. N. Engl. J. Med. 255: 449-456.

24. Weissmann, G., R. B. Zurier, P. J. Spieler, and I. M. Goldstein. 1971. Mechanisms of lysosomal enzyme release from leukocytes exposed to immune complexes and other particles. J. Exp. Med. 134: 149s-165s.

25. Lowry, O. H., N. J. Rosebrough, A. L. Farr, and R. J. Randall. 1951. Protein measurement with the Folin phenol reagent. J. Biol. Chem. 193: 265-275.

26. Bray, G. A. 1960. A simple efficient liquid scintillator for counting aqueous solutions in a liquid scintillation counter. Anal. Biochem. 1: 279-285.

27. Goldstein, I. M., and G. Weissman, 1974. Generation of C5-derived lysosomal enzyme-releasing activity (C5a) by lysates of leukocyte lysosomes. J. Immunol. 113: 15831588.

28. Tinberg, H. M., R. L. Melnick, J. Maguire, and L. Packer. 1974. Studies on mitochondrial proteins. II. Localization of components in the inner membrane: labeling with diazobenzenesulfonate, a nonpenetrating probe. Biochim. Biophys. Acta. 345: 118-128.

29. Sharon, N., and H. Lis. 1972. Lectins: cell-agglutinating and sugar-specific proteins. Science (Wash. D. C.). 177: 949-959.

30. Salin, M. L., and J. M. McCord. 1975. Free radicals and inflammation. Protection of phagocytosing leukocytes by superoxide dismutase. J. Clin. Invest. 56: 1319-1323.

31. Weening, R. S., R. Wever, and D. Roos. 1975. Quantitative aspects of the production of superoxide radicals by phagocytizing human granulocytes. J. Lab. Clin. Med. 85: 245-252.

32. Howard, A. N., and F. Wild. 1957. The reactions of diazonium compounds with amino acids and proteins. Biochem. J. 65: 651-659.

33. Higgins, H. G., and K. J. Harrington. 1959. Reaction of amino acids and proteins with diazonium compounds. II. Spectra of protein derivatives. Arch. Biochem. Biophys. 85: 409-425. 